\title{
BANK SYARIAH DALAM PERSPEKTIF FILOSOFIS, YURIDIS DAN SOSIOLOGIS BANGSA INDONESIA
}

\author{
Ahmad Supriyadi* \\ e-mail: supriyadi515@yahoo.com
}

\begin{abstract}
Islamic bank is a financial institution that is essential for the people of Indonesia as an institution that is able to portray a welfare society with its products when it is implemented consistently. But the understanding of Islamic banks in the community is still in doubt because of Islamic bank same as conventional banks. Improper understanding of it can be explained by the philosophical, juridical and sociological. Islamic banking is a bank in its operations based on Islamic principles both in raising funds and mudaraba wadiah principles; in financing the purchase using the principles of Murabaha, salam and istishna; the issuing bank services products sharia apply the principle of al-wakalah, al-Hiwalah, al-qardh, al-kafalah, and al-Rahn. Three products when viewed legally has implemented of Constitution Number 21 concerning Islamic banking, and in a philosophical perspective in accordance with Pancasila, grand norm Constitution the 1945 and the Quran-Hadith, whereas in sociological perspective these principles have been entrenched in Indonesian society cooperation in agriculture "maro, mertelu" in livestock typically "mertelu", so it is said that the sociological principles of Sharia have been popular in Indonesia society.
\end{abstract}

Keywords : philosophy, juridical, sociology.

\section{A. PENDAHULUAN}

Bank syariah merupakan lembaga keuangan yang mempunyai peranan penting bagi bangsa Indonesia. Semua kegiatan usaha sekarang ini selalu melibatkan pihak perbankan baik usaha kecil, menengah apalagi usaha besar. Pengusaha dalam melakukan bisnisnya selalu membutuhkan dana untuk pengembangan usaha dari pihak perbankan bahkan untuk kegiatan pengiriman uang dan juga penjaminan dalam bertransaksi. Pekerjaan profesi juga banyak menggunakan jasa perbankan terutama pada transfer uang atau juga pengembangan kantor dan lain sebagainya. Para petani yang menggarap lahan luas juga memerlukan dana untuk mengolah sawah atau kebun. Petani Tebu yang ada di sekitar eks karesidenan Pati hampir semuanya mengambil pinjaman dana dari pihak perbankan. Para pedagang kaki lima juga tidak ketinggalan menggunakan jasa perbankan dalam pengembangan usahanya, maka semua aspek banyak yang melibatkan lembaga perbankan. 
Pentingnya peran perbankan di masyarakat memunculkan sebuah pertanyaan besar kepada lembaga perbankan syariah dari sisi filososfis, yuridis, normatif dan sosiologis. Pertanyaan ini muncul dilandasi atas fakta-fakta yang ada: Pertama, negara Indonesia merupakan negara pancasila, walaupun negara melindungi kepentingan melaksanakan agama masing-masing, tetapi fakta selama kurun waktu dari kemerdekaan hingga tahun 1990-an kegiatan keagamaan bagi umat Islam banyak dicurigai oleh pemerintah Orde Baru, bahkan peristiwaperistiwa yang terjadi di tanah air berkaitan dengan bom atau bom bunuh diri banyak dicurigai yang melakukan adalah umat Islam. Tidak pernah agama lain itu dicurigai sebagai aktor dibalik bom yang ada di tanah air. Padahal belum tentu yang melakukan orang Islam itu aktornya orang Islam, karena bom itu diperlukan dana besar dan umat Islam hanya memiliki dana kecil dan yang memiliki dana besar adalah orang non muslim.

Kedua, pada awal berdirinya bank syariah, banyak orang meragukan eksistensinya di masyarakat. Banyak orang mengatakan bahwa bank syariah akan ada seumur jagung di Indonesia, namun kenyataan mumbuktikan bahwa bank syariah tetap eksis hingga sekarang dan berkembang pesat. Hal itu menunjukkan bahwa anti tesis masyarakat yang menolak bank syariah dapat terbantahkan dengan keberadaan bank syariah sekarang ini yang eksis.

Ketiga, bank syariah perlu ada kajian secara filosofis, yuridis, normatif dan sosiologis. Masyarakat masih banyak yang bertanya-tanya apa itu bank syariah dan bagaimana kebenarannya secara hukum di Indonesia. Pertanyaan itu muncul seiiring dengan kurangnya masyarakat berafiliasi kepada bank syariah bila dilihat lima tahun terakhir ini dan bila diukur dengan rasio perbandingan antara jumlah penduduk yang beragama Islam yang menjadi nasabah bank syariah dengan yang tidak menjadi nasabah bank syariah. Masih banyak umat Islam yang belum menjadi nasabah bank syariah dibanding dengan yang sudah menjadi nasabah. Fakta ini sangat memprihatinkan, tetapi itu tidak menyelesaikan masalah, maka perlu dicari kebenaran bank syariah dari sisi filosofis, yuridis, normatif dan sosiologis.

\section{B. PEMBAHASAN}

\subsection{Bank Syariah di Indonesia}

Pemahaman bank syariah dapat didekati melalui tiga cara untuk mendefinisikan apa itu bank syariah. Pertama, berdasarkan pada peraturan perundang-undangan (legal regulation within which the institutional function), kedua, berdasarkan pada kegiatan bank atau services bank terhadap jasa yang ditawarkan kepada konsumen, ketiga, berdasarkan fungsi ekonomis (economic fungtions) atas bank seperti yang ditunjukkan ketika melayani masyarakat. ${ }^{1}$

1 Jonathan R. Macey and Miller, Geoffrey, P. Banking law and Regulation, Littlle, Brown and Company, Boston, Toronto, London, 1992 hal. 36-37 dalam Nindyo Pramono, Hukum Perbankan Suatu Kajian dari Perspektif Hukum Ekonomi, disampaikan dalam Penataran Dosen Hukum Perdata dan Ekonomi 
Pertama, berdasarkan Undang-Undang Nomor 21 Tahun 2008 tentang Perbankan Syariah, dan Undang-Undang Nomor 10 Tahun 1998 jo. UU No. 7 Tahun 1992, ketiganya mempunyai pengertian yang sama tentang bank yaitu badan usaha yang menghimpun dana dari masyarakat dalam bentuk simpanan dan menyalurkannya kepada masyarakat dalam rangka meningkatkan taraf hidup rakyat banyak. Sedangkan bank syariah adalah bank yang menjalankan kegiatan usahanya berdasarkan prinsip syariah dan menurut jenisnya terdiri atas Bank Umum Syariah dan Bank Pembiayaan Rakyat Syariah. Kedua, pengertian bank dapat diperjelas berdasarkan produk yang ditawarkan kepada konsumen, bahwa bank adalah institusi yang menerima simpanan uang dan menyalurkannya kepada masyarakat, serta menyediakan jasa lainnya. Ketiga, pengertian bank dengan pendekatan fungsi ekonomi, bahwa bank adalah lembaga yang menerima simpanan uang dan menyalurkannya kepada usaha kegiatan ekonomi dan juga melakukan kegiatan jasa lainnya. ${ }^{2}$

Berdasarkan ketiga pendekatan tersebut tentang pengertian bank adalah lembaga jasa keuangan yang melaksanakan usaha menghimpun dana dari masyarakat dan menyalurkannya kepada masyarakat dalam bentuk pembiayaan atau pinjaman serta kegiatan ekonomi lainnya dalam bentuk jasa. Bank syariah yang merupakan salah satu perbankan di Indonesia dapat diartikan sebagai badan usaha bidang keuangan yang kegiatannya melakukan penghimpunan dana dari masyarakat dan menyalurkannya kepada masyarakat dalam bentuk pembiayaan atau pinjaman serta melakukan kegiatan ekonomi lainnya dalam bentuk jasa yang berdasarkan prinsip syariah.

Berdasarkan pengertian tersebut, bank syariah merupakan bank yang memiliki ciri khusus dalam operasionalnya dengan menerapkan syariah yaitu berbagi keuntungan dan kerugian baik dalam penghimpunan dana dan pembiayaan maupun dalam produk jasa. ada perbedaan antara bank berdasarkan prinsip syariah, dibanding dengan bank konvensional yaitu bank syariah melakukan usaha berdasarkan prinsip berbagi keuntungan dan kerugian, sedangkan bank konvensional melakukan penghimpunan dana dan penyaluran dana dalam bentuk kredit berbasis bunga. Kedua perbankan tersebut memiliki sistem hukum yang berbeda-beda sesuai dengan basisnya.

\subsection{Produk-Produk Bank Syariah}

\section{a. Produk Penghimpunan Dana Bank Syariah}

Penghimpunan dana di Bank Syariah menerapkan prinsip wadi'ah dan prinsip mudharabah. Kedua prinsip tersebut diimplementasikan oleh bank syariah

seluruh Indonesia yang diselenggarakan oleh Fakultas Hukum UGM 18-23 September 2000 di Yogyakarta, hal. 1

2 Ibid Jonathan R. Macey and Miller, Geoffrey, P., hal. 38. 
dalam penghimpunan dana berupa: giro, tabungan dan deposito (M. Syafi'i Antonio, 2001: 155).

Hal itu didasarkan pada Undang-Undang Perbankan Syariah Nomor 21 Tahun 2008 Pasal 19 menyatakan bahwa kegiatan usaha Bank Umum Syariah meliputi:

1. Menghimpun dana dalam bentuk Simpanan berupa Giro, Tabungan, atau bentuk lainnya yang dipersamakan dengan itu berdasarkan Akad wadi'ah atau Akad lain yang tidak bertentangan dengan Prinsip Syariah;

2. Menghimpun dana dalam bentuk Investasi berupa Deposito, Tabungan, atau bentuk lainnya yang dipersamakan dengan itu berdasarkan Akad mudharabah atau Akad lain yang tidak bertentangan dengan Prinsip Syariah;

Pasal tersebut menunjukkan bahwa Bank Syariah dalam penghimpunan dana menjalankan produk : simpanan yang terdiri dari giro dan tabungan serta investasi yang terdiri dari deposito dan tabungan.

Di sini akan dijelaskan lebih lanjut tentang penghimpunan dana.

1) Produk Giro

Giro menurut Pasal 1 UU Nomor 21 Tahun 2008 tentang Perbankan Syariah adalah simpanan berdasarkan akad wadi'ah atau akad lain yang tidak bertentangan dengan prinsip syariah yang penarikannya dapat dilakukan setiap saat dengan menggunakan cek, bilyet giro, sarana perintah pembayaran lainnya, atau dengan perintah pemindahbukuan.

Menurut M. Syafi'i Antonio (2001: 155) giro di Bank Syariah pada umumnya menggunakan akad wadi'ah dan mudharabah. Akad wadi'ah di terapkan untuk safe deposit box atau titipan murni. Jadi bank tidak boleh menggunakan dana tersebut. Disini bank akan meminta uang jasa penitipan murni. Adapun wadi'ah yad dhamanah adalah titipan kepada bank yang mana bank hanya bertanggung jawab pada nilai uangnya dan bukan fisiknya, sehingga bank bisa menggunakannya.

Menurut fatwa Dewan Syariah Nasional (DSN) giro wadi'ah harus mengikuti ketentuan sebagai berikut :

a) Bersifat simpanan

b) Simpanan bisa diambil kapan saja (on call) atau berdasarkan kesepakatan

c) Tidak ada imbalan yang disyaratkan, kecuali dalam bentuk pemberian yang bersifat sukarela dari pihak bank.

Giro wadi'ah mempunyai karakteristik:

a) Harus dikembalikan utuh seperti semula yaitu tidak boleh overdraft

b) Dapat dikenakan biaya titipan

c) Dapat diberikan syarat tertentu untuk keselamatan barang titipan berupa saldo minimum

d) Penarikan giro wadi'ah diakukan dengan cek dan bilyet giro sesuai ketentuan yang berlaku. 
e) Jenis dan kelompok rekening sesuai ketentuan yang berlaku yaitu sepanjang tidak bertentangan dengan syariah.

f) Dana wadi'ah hanya dapat digunakan seijin penitip.

2) Produk Tabungan

Tabungan menurut Undang-Undang Nomor 21 Tahun 2008 tentang Perbankan Syariah adalah simpanan berdasarkan akad wadi'ah atau investasi dana berdasarkan akad mudharabah atau akad lain yang tidak bertentangan dengan prinsip syariah yang penarikannya hanya dapat dilakukan menurut syarat dan ketentuan tertentu yang disepakati, tetapi tidak dapat ditarik dengan cek, bilyet giro dan atau alat lainnya yang dipersamakan dengan itu.

Menurut fatwa Dewan Syariah Nasional (DSN) Bahwa dalam tabungan mudharabah harus memenuhi ketentuan berikut ini:

a) Nasabah bertindak sebagai shahibul maal atau pemilik dana, dan bank bertindak sebagai mudharib atau pengelola dana.

b) Bank dapat melakukan berbagai macam usaha yang tidak bertentangan dengan prinsip syariah dan mengembangkannya, termasuk di dalamnya mudharabah dengan pihak lain

c) Modal harus dinyatakan dengan jumlahnya, dalam bentuk tunai dan bukan piutang.

d) Pembagian keuntungan harus dinyatakan dalam bentuk nisbah dan dituangkan dalam akad pembukaan rekening.

e) Mudharib menutup biaya operasional tabungan dengan menggunakan nisbah keuntungan yang menjadi haknya

f) Bank tidak diperkenankan mengurangi nisbah keuntungan nasabah tanpa persetujuan yang bersangkutan.

3) Produk Deposito

Deposito menurut Undang-Undang Nomor 21 Tahun 2008 tentang Perbankan Syariah adalah investasi dana berdasarkan akad mudharabah atau akad lain yang tidak bertentangan dengan prinsip syariah yang penarikannya hanya dapat dilakukan pada waktu tertentu berdasarkan akad antara nasabah penyimpan dan Bank Syariah dan atau UUS.

Menurut fatwa Dewan Syariah Nasional (DSN) deposito mudharabah harus mengikuti ketentuan sebagai berikut :

a) Nasabah bertindak sebagai shahibul maal atau pemilik dana, dan bank bertindak sebagai mudharib atau pengelola.

b) Bank dapat melakukan berbagai macam usaha yang tidak bertentangan dengan prinsip syariah dan mengembangkannya, termasuk di dalamnya mudharabah dengan pihak lain.

c) Modal harus dinyatakan dengan jumlahnya, dalam bentuk tunai dan bukan piutang 
d) Pembagian keuntungan harus dinyatakan dalam bentuk nisbah dan dituangkan dalam akad pembukaan rekening

e) Mudharib menutup biaya operasional deposito dengan menggunakan nisbah keuntungan yang menjadi haknya.

f) Bank tidak diperkenankan untuk mengurangi nisbah keuntungan.

\section{b. Penyaluran Dana/Pembiayaan di Bank Syariah}

Penyaluran dana atau pembiayaan di bank syariah dilakukan dengan berbagai teknik, secara garis besar terbagi dalam empat kategori yang dibedakan berdasarkan tujuan penggunaannya, yaitu:

1) pembiyaan dengan akad jual beli menggunakan prinsip syariah: jual beli murabahah, salam dan istishna

2) pembiayaan dengan sewa menggunakan prinsip syariah: ijarah

3) pembiayaan dengan akad bagi hasil menggunakan prinsip syariah: mudharabah dan musyarakah

4) pembiayaan dengan akad pelengkap menggunakan prinsip syariah: wakalah

Pembiayaan dengan akad jual-beli ditujukan untuk memiliki barang, sedangkan yang menggunakan akad sewa ditujukan untuk mendaptkan jasa. akad bagi hasil digunakan untuk usaha kerja sama yang ditujukan guna mendapatkan barang dan jasa sekaligus

a. Prinsip jual-beli

Transaksi jual-beli dapat dibedakan berdasarkan bentuk pembayarannya dan waktu penyerahan barangnya, yakni :

(1) Jual-beli murabahah

Murabahah merupakan produk bank syariah yang paling populer digunakan dalam pembiayaan. Jual-beli murabahah adalah transaksi jual-beli dimana bank menyebut jumlah keuntungannya, bank bertindak sebagai penjual, sementara nasabah sebagai pembeli. Harga jual adalah harg beli bank dari pemasok ditambah keuntungan (margin) misalnya 10\% atau 20\%.

Kedua belah pihak harus menyepakati harga jual dan jangka waktu pembayaran. Harga jual dicantumkan dalam akad jual-beli dan jika telah disepakati tidak dapat berubah selama berlakunya akad. Dalam perbankan, murabahah selalu dilakukan dengan cara pembayaran cicilan (bi-tsamani ajil). Dalam transaksi ini barang diserahkan segera setelah akad, sementara pembayaran dilakukan secara tangguh / cicilan.

Mekanisme bai' al-murabahah (jual beli) dapat dijelaskan melalui gambar berikut ini: 


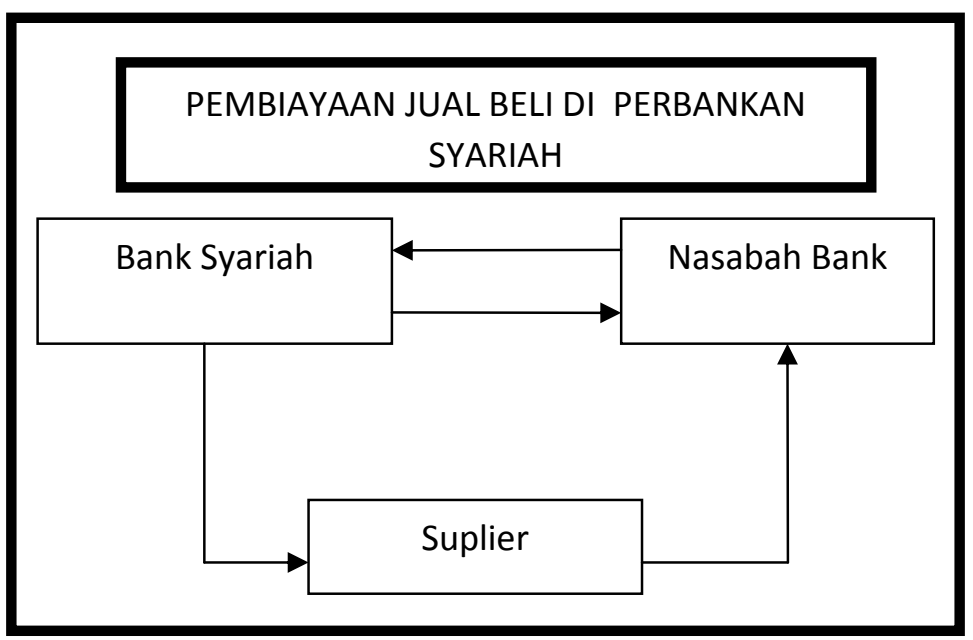

Gambar: Mekanisme Bai' al-Murabahah

(2) Jual-beli salam

Jual-beli salam dalam perbankan syariah merupakan jual beli dengan cara memesan suatu barang, tetapi pembayaran telah dilakukan secara tunai. Salam adalah transaksi jual-beli dimana barang yang diperjual belikan belum ada. Oleh karena itu, barang diserahkan secara tangguh sementara pembayaran dilakukan tunai. Bank bertindak sebagai pembeli, sementara nasabah sebagai penjual. Dalam praktik perbankan, ketika barang telah diserahkan kepada bank, maka bank akan menjualnya kepada rekanan nasabah atau kepada nasabah itu sendiri secara tunai atau cicilan. Harga jual yang ditetapkan oleh bank adalah harga beli bank dari nasabah ditambah keuntungan. Dalam hal bank menjualnya secara tunai biasanya disebut pembiayaan talangan (bridging financing). Sedangkan dalam hal bank menjualnya secara cicilan, kedua pihak harus menyepakati harga jual dan jangka waktu pembayaran (M. Syafi'I Antonio, 2001: 105)..

Ketentuan umum jual-beli salam adalah sebagai berikut:

(a) Pembelian hasil produksi harus diketahui spesifikasinya secara jelas seperti jenis, macam, ukuran, mutu dan jumlahnya. Misalnya jual-beli $100 \mathrm{~kg}$. Mangga Harum Manis kualitas A dengan harga Rp. 5000/Kg., akan diserahkan pada panen dua bulan mendatang.

(b) Apabila hasil produksi yang diterima cacat atau tidak sesuai dengan akad maka nasabah (produsen) harus bertanggung jawab dengan cara antara lain mengembalikan dana yang telah diterimanya atau mengganti barang yang sesuai dengan pesanan

(c) Mengingat bank tidak menjadikan barang yang dibeli atau dipesannya sebagai persediaan (inventory), maka dimungkinkan bagi bank untuk melakukan akad salam kepada pihak ketiga (pembelian kedua), seperti 
BULOG, pedagang pasar induk atau rekanan. Mekanisme seperti ini disebut dengan paralel salam.

(3) Jual-beli istishna

Istishna' berarti meminta dibuatkan suatu barang artinya kontrak yang ditandatangani bersama antara pemesan dengan produsen untuk pembuatan suatau jenis barang tertentu. Biasanya, jenis ini dipergunakan dibidang manufaktur. Dengan demikian, ketentuan istishna mengikuti ketentuan dan aturan akad bai' salam. Produk istishna pembayarannya dapat dilakukan oleh bank dalam beberapa kali (termin) pembayaran. Akad tersebut bila diterapkan di Perbankan Syariah adalah untuk pembiayaan modal kerja bagi para pengusaha yang akan memproduksi barang.

b) Prinsip Sewa (Ijarah)

Al-ijarah adalah pemindahan hak guna atas barang atau jasa, melalui pembayaran upah sewa, tanpa diikuti dengan pemindahan kepemilikan (ownership) atas barang itu sendiri. Transaksi ijarah dilandasi adanya perpindahan manfaat. Jadi pada dasarnya prinsip ijarah sama saja dengan prinsip jual beli, tapi perbedaannya terletak pada objek transaksinya. Bila pada jual-beli objek transaksinya adalah barang, pada ijarah objek transaksinya adalah jasa.

c) Prinsip Bagi Hasil

Produk pembiayaan bank syariah yang didasarkan atas prinsip bagi hasil terdiri dari al-musyarakah dan al-mudharabah.

i. Musyarakah

Musyarakah adalah kerja sama antara dua pihak atau lebih untuk melakukan suatu usaha tertentu dimana masing-masing pihak memberikan kontribusi dana dengan kesepakatan bahwa keuntungan dan risiko akan ditanggung bersama sesuai kontribusi dana.

ii. Mudharabah

Mudharabah berasal dari kata adh-dharbu yaitu bepergian untuk urusan dagang. Firma Allah dalam durat 73 ayat 20 "mereka berpergian di muka bumi mencari karunia Allah". Secara teknis, al-mudharabah adalah akad kerja sama usaha antara dua pihak dimana pihak pertama (shahibul maal) menyediakan seluruh (100\%) modal, sedangkan pihak lainnya menjadi pengelola. Keuntungan usaha secara mudharabah dibagi menurut kesepakatan yang dituangkan dalam kontrak.

Bank Syariah selain mempunyai produk penghimpunan dana dan produk penyaluran dana, ia juga mempunyai produk jasa. Dalam hal ini Bank Syariah dapat melakukan berbagai pelayanan jasa perbankan kepada nasabah dengan mendapatkan imbalan berupa sewa atau keuntungan.

\section{c. Produk Jasa Perbankan syariah}


Produk jasa perbankan syariah menggunakan prinsip-prinsip tersebut antara lain: al-wakalah, al-hiwalah, al-qardh, al-kafalah dan al-rahn, dari prinsip-prinsip ini perbankan syariah menjalankan berbagai produk jasa.

\subsection{Bank Syariah dalam Perspektif Filosofis, Yuridis dan Sosiologis}

Indonesia telah melakukan pembangunan hukum berkaitan dengan sistem hukum perbankan syariah melalui undang-undang nomor 21 tahun 2008 tentang perbankan syariah. sistem hukum perbankan syariah yang dibangun sekarang ini merupakan lembaga keuangan yang ideal di Indonesia baik dari sisi filososfis, yuridis dan sosiologis.

Secara filosofis, perbankan syariah merupakan lembaga keuangan yang sesuai dengan ideologi bangsa Indonesia yaitu Pancasila dan pembukaan UndangUndang Dasar 1945. ${ }^{3}$ Pancasila yang memberikan landasan nilai-nilai mulai dari sila pertama "Ketuhanan Yang Maha Esa, hingga sila kelima "Keadilan Sosial Bagi Seluruh Rakyat Indonesia" kelima sila itu tidak ada satupun yang bertentangan dengan perbankan syariah yang menerapkan prinsip syariah berbagi keuntungan dan kerugian. Begitu pula bank syariah sudah sesuai dengan pembukaan UUD 1945 yang menggariskan suatu cita-cita sebagai negara Indonesia yang adil dan makmur, yang juga merupakan salah satu tujuan sistem hukum perbankan syariah di Indonesia. 4

Indonesia yang mayoritas penduduknya muslim, bank syariah secara filosofis tidak hanya berdasarkan Pancasila dan UUD 1945 tetapi juga mempunyai landasan yang kokoh berdasarkan hukum Islam yaitu sesuai dengan al-Qur'an dan Hadis terutama dalam hal larangan menjalankan ekonomi dengan riba bagi umat Islam. Muamalah yang telah dilandasi dengan al-Qur'an dan hadis menurut teori syahadah bahwa setiap muslim yang telah bersyahadat memeluk agama Islam punya konskuensi logis wajib menjalankan syariah Islam, sebagaimana diwajibkan dalam al-Qur'an surat ke 1 (5), surat ke 2 (179), surat ke 3 (7), surat ke 4 ayat $(13,14,49,63$, 69 dan 109), surat ke 5 (44, 45, 47, 48, 49 dan 50), surat ke 24 (51 dan 52). Teori syahadat ini kelanjutan dari prinsip tauhid dalam filsafat hukum Islam. Prinsip tauhid mewajibkan kepada setiap orang yang beriman kepada Allah yang maha esa, maka ia wajib taat dan patuh terhadap perintah Allah dalam al-Qur'an dan perintah Rasulullah dalam sunahnya. ${ }^{5}$

Filosofi keberadaan bank syariah di Indonesia yang berdasarkan al-Qur'an dan hadis tersebut diimplementasikan dalam prinsip berbagi keuntungan dan

3 Mustaghfirin, Rekonstruksi Sistem Hukum Perbankan di Indonesia Kajian dari Aspek Filososfis, Sosiologis dan Budaya, Unissula Press, Semarang, 2006, hal. 9-16. Dan Dadan Muttaqien, Sistem Perbankan Syariah di Indonesia dalam Perspektif Politik Hukum, Disertasi Universitas Diponegoro, Semarang, 2007, hal. 361.

4 Undang-Undang Nomor 21 Tahun 2008 Tentang Perbankan Syariah pasal 1

5 Juhaya S. Praja, Epistemologi Syara' mencari Format Baru Figh Indonesia, Pustaka Pelajar, Yogyakarta, 2009, hal. 125 
kerugian yang adil bagi semua pihak, baik bagi nasabah dan juga bagi lembaga perbankan syariah. Atas dasar filosofi tersebut, perbankan syariah merupakan lembaga yang sangat ideal bagi bangsa Indonesia, sehingga implementasinya juga seharusnya sesuai dengan landasan filosofi yang mendasarinya.

Filosofi tersebut mendudukkan lembaga perbankan syariah mempunyai peranan dan fungsi yang sangat penting dalam kehidupan khususnya bangsa Indonesia. Sebagai negara berkembang yang sedang giat-giatnya melakukan pembangunan di segala bidang dengan tujuan mewujudkan masyarakat adil dan makmur berdasarkan Pancasila dan Undang-Undang Dasar 1945. 6 Peranan perbankan syariah bagi bangsa Indonesia adalah menyelesaikan masalah ekonomi, sosial, budaya, pendidikan dan juga politik.

Peranan dan fungsi bank dalam kontek usaha adalah sebagai financialintermediary antara pemilik dana dengan pengusaha yang mengelola dana, sekaligus mempunyai peran penting dalam dua hal yaitu melaksanakan amanat UUD 1945 tentang pemerataan ekonomi bagi masyarakat dan juga mendukung pembangunan ekonomi negara. Karena itu usaha perbankan sering disebut jantungnya penggerak roda perekonomian suatu negara, maka bila perbankan mengalami kehancuran di suatu negara, akibatnya terpuruk pula ekonomi negara tersebut sebagaimana yang dialami Indonesia. ${ }^{7}$ Sekarang ini hampir tidak ada yang tidak berurusan dengan bank baik sebagai penabung maupun peminjam dana, maka tidak bisa dipungkiri kalau saat ini bank sebagai kebutuhan primer juga. Fakta yang ada di sekeliling kita tentang penggunaan jasa perbankan adalah pembayaran listrik, PAM dan pembayaran uang kuliah, semua itu membutuhkan jasa bank dalam pelayanan keuangan berkaitan pembayaran.

Berlandaskan filosofi yang kokoh tersebut juga lahir fungsi perbankan syariah yang ideal dengan produk-produk perbankan syariah yang menerapkan berbagi keuntungan dan kerugian. Berdasarkan fungsinya bank mempunyai tiga fungsi yaitu fungsi penghimpunan dana, fungsi penyaluran dana dan fungsi memperlancar lalu lintas pembayaran. Selain ketiga fungsi tersebut, bagi perbankan syariah ditambah satu fungsi yaitu fungsi sosial yang berkaitan dengan penghimpunan dana zakat, infaq, sadaqah dan menyalurkannya kepada yang berhak.

Pertama, fungsi penghimpunan dana. Dana yang ada di bank tidak semuanya milik lembaga, ada sebagian atau sebagian besar milik nasabah atau

\footnotetext{
${ }^{6}$ Djuhaendah Hasan, Analisis Hukum Ekonomi Terhadap Hukum Perbankan di Indonesia, disampaikan dalam Penataran Dosen Hukum Perdata dan Ekonomi seluruh Indonesia yang diselenggarakan oleh Fakultas Hukum UGM 18-23 September 2000 di Yogyakarta, hal. 5. lihat juga UU Nomor 7 Tahun 1992 tentang Perbankan dalam C. S. T. Kansil dan Christine S. T. Kansil, Kitab Undang-Undang Perusahaan, Pradnya Paramita. Jakarta, 2001, hal. 571.

${ }^{7}$ Hikmanto Juwana, Analisa Ekonomi Atas Hukum Perbankan, makalah disampaikan dalam " seminar tentang "Pendekatan Ekonomi Dalam Pengembangan Sistem Hukum Nasional Dalam Rangka Globalisasi" diselenggarakan oleh Fakultas Hukum UNPAD bekerjasama dengan Bappenas, Bandung, 30 April 1998
} 
masyarakat investor dan ada juga sebagian modal milik bank itu sendiri. Penghimpunan dana bagi bank sudah merupakan kegiatannya yang dilindungi oleh undang-undang, karena itu modal utama bagi bank adalah kepercayaan. Masyarakat akan menaruh uangnya di bank tertentu, bila ia sudah percaya dan yakin bahwa uangnya akan kembali dan sebaliknya masyarakat akan menarik uangnya secara tiba-tiba bila tidak percaya kepada bank itu, sebagaimana terjadi peristiwa tahun 1998 banyak masyarakat yang menarik uangnya dari bank, karena merasa tidak aman uangnya di bank.

Fasilitas penghimpunan dana ini bank mengeluarkan berbagai produk investasi antara lain : tabungan, simpanan giro, dan deposito ${ }^{8}$. Melalui produk tersebut masyarakat dapat menyimpan dananya di bank dengan aman dan dapat ditarik kembali sesuai dengan perjanjian.

Fungsi ke dua adalah menyalurkan kredit atau pembiayaan di bank syariah. Dana yang diperoleh dari masyarakat investor, dikelola oleh bank dengan menyalurkan kredit atau pembiayaan. Pada umumnya baik kredit maupun pembiayaan ada dua kategori yaitu ada yang berjangka pendek dan ada yang berjangka panjang. Dalam kontek bank syariah, produk pembiayaan yang dilakukan dengan jangka pendek berupa jual beli murabahah, salam dan istishna, ada juga gadai (rahn), pinjaman murni (Qardh) dan juga sewa (ijarah), sedangkan pembiayaan dalam jangka panjang pada umumnya melalui mudharabah dan musyarakah. 9

Fungsi ke tiga adalah melancarkan lalu lintas pembayaran. Bank syariah melaksanakan usaha tersebut sering disebut jasa. Jasa yang dilakukan oleh bank syariah berupa hiwalah (transfer uang), kafalah (asuransi), wakalah (perwakilan). ${ }^{10}$

Fungsi bank syariah ke empat sebagai tambahan, bahwa bank syariah dapat menjalankan sebagai pengelola zakat, infaq dan sadaqah. Masyarakat yang percaya kepada bank syariah tidak perlu bersusah payah membagi zakat sendirian dan mencari orang-orang yang berhak menerima zakat, tetapi ia bisa menyerahkannya kepada bank syariah untuk melaksanakan pembagian zakat dan mencari para mustahiq.

Memperhatikan peran bank sebagai intermediary yang menghubungkan antara sahibulmaal dengan pengusaha, 11 maka peran bank di dalam kehidupan sehari-hari merupakan lembaga yang primer dalam kajian ke-Islam-an atau disebut

\footnotetext{
${ }^{8}$ Undang-Undang Nomor 21 Tahun 2008 tentang Perbankan Syariah dan Peraturan Bank Indonesia Nomor: 9/19/PBI/2007 sebagaimana diubah menjadi Peraturan Bank Indonesia Nomor : 10/16/2008 tentang Pelaksanaan prinsip syariah dalam Kegiatan Penghimpunan dana dan penyaluran dana serta pelayanan jasa bank syariah.

${ }_{9}^{9}$ Ibid, pasal 1 ayat 8. Sebagaimana dalam buku : Adiwarman A. Karim, Bank Islam Analisis Fiqih dan Keuangan, PT. Raja Grafindo Persada, Jakarta, 2010, hal. 203-213

${ }^{10} \mathrm{Ibid}$, pasal 1 ayat 8. Sebagaimana dalam buku : Muhammad Syafi'I Antonio, Bank Syariah Dari Teori ke Praktik, Gema Insani, Jakarta, 2001, hal. 137-139.

${ }^{11}$ Heri Sudarsono, Bank dan Lembaga Keuangan Syari'ah Deskripsi dan Ilustrasi, Penerbit Ekonisia UII, Yogya, 2004, hal. 5
} 
kebutuhan dharuri. Kebutuhan dharuri dalam hal keuangan dapat didekati dengan teori maslahah bahwa menurut teori maslahah ada lima kebutuhan primer yang harus terpenuhi dalam kehidupan manusia yaitu : menjaga agama, menjaga akal, menjaga jiwa, menjaga harta dan menjaga keturunan. Keberadaan lembaga keuangan merupakan masuk dalam kebutuhan menjaga harta. ${ }^{12}$ Pada saat khalifah Abu bakar memimpin, yang pertama kali diperangi adalah orang-orang yang tidak membayar zakat, artinya dalam hal kenegaraan harta juga menjadi kebutuhan primer atau dharuri, sehingga keberadaan lembaga keuangan menjadi kebutuhan utama juga.

\subsection{Bank Syariah Berdasarkan Yuridis}

Keberadaan Bank syariah di Indonesia juga sesuai dengan landasan yuridis atau perundang-undangan yang ada di Indonesia. Sejak dicetuskannya gagasan perbankan syariah, perundang-undangan yang lahir adalah Undang-Undang Nomor 7 Tahun 1992 tentang Perbankan yang dibarengi dengan lahirnya Peraturan Pemerintah Nomor 72 Tahun 1992 tentang Bank Berdasarkan Prinsip Bagi Hasil. Kemudian undang-undang tersebut diubah dengan Undang-Undang Nomor 10 tahun 1998 tentang perbankan, kemudian diatur dengan perundang-undangan sendiri yaitu Undang-Undang Nomor 21 Tahun 2008 tentang Perbankan Syariah. Selain perundang-undangan, perbankan syariah diatur juga dalam Peraturan Bank Indonesia, kompilasi hukum ekonomi syariah dan fatwa Dewan Syariah Nasional.

\subsection{Bank Syariah Berdasarkan Sosiologis}

Bank syariah secara sosiologis juga sesuai dengan kebutuhan masyarakat Indonesia. Pertama, mayoritas penduduk Indonesia adalah muslim yang membutuhkan bank yang sesuai dengan prinsip Islam yaitu berbagi keuntungan dan kerugian, kedua praktik perbankan syariah bagi hasil sudah merupakan bagian dari budaya masyarakat Indonesia yang dalam berbagai kegiatan ekonomi selalu menerapkan "“ maro, mertelu" dalam hal perdagangan, pertanian, kelautan dan juga peternakan. ${ }^{13}$ Maka menurut Dadan Muttaqien perbankan syariah sudah menjadi sine quanon keberadaannya di Indonesia, karena sesuai dengan budaya bangsa dan kegiatan usaha yang dijalankan oleh bangsa Indonesia.

Pembangunan hukum perbankan syariah yang ideal tersebut faktanya masih ada kelemahan terutama dalam hal mencapai tujuan keadilan yang diidamidamkan oleh masyarakat Indonesia dalam membentuk lembaga perbankan syariah. Padahal umur perbankan syariah sekarang ini sudah lebih dari 23 tahun di mulai dari undang-undang Nomor 7 tahun 1992 yang mengatur tentang bagi hasil, hingga saat ini tahun 2015. Sebuah umur yang cukup panjang karena bila diukur dengan perkembangan manusia, umur 23 tahun merupakan umur bagi para remaja

12 Ismail Muhammad Syah, Filsafat hukum Islam, Bumi Aksara, Jakarta, 1999, hal. 67-101.

${ }^{13}$ Dadan Muttaqien, Sistem Perbankan Syariah di Indonesia dalam Perspektif Politik Hukum, Disertasi Universitas Diponegoro, Semarang, 2007, hal. 361 
yang telah memasuki usia dewasa dan matang. Selayaknya hukum perbankan syariah sudah mencapai kemapanan yang menerapkan keadilan dalam praktik prinsip berbagi keuntungan dan kerugian.

Keadilan menjadi panglima dalam implementasi perbankan syariah sesuai dengan amanat Undang-Undang Nomor 21 Tahun 2008 tentang Perbankan Syariah, karena sejatinya keberadaan perbankan syariah adalah untuk melaksanakan keadilan di bidang ekonomi. Hal itu sesuai dengan tujuan hukum berdasarkan teori yaitu: 14

1) Teori etis. Menurut teori etis, hukum itu bertujuan untuk melaksanakan keyakinan manusia yang etis yaitu keadilan.

2) Teori utilitis. Menurut teori utilitis, hukum itu untuk menjamin kebahagiaan yang terbesar bagi manusia, jadi hukum dilihat dari sisi kemanfaatannya bagi manusia yaitu untuk memberikan kenyamanan dan kebahagiaan bagi manusia.

3) Teori campuran. Menurut teori campuran yang dianut oleh Mochtar Kusumaatmadja bahwa tujuan hukum adalah ketertiban. Ketertiban merupakan kebutuhan masyarakat yang utama, namun selain ketertiban, hukum juga untuk mencapai keadilan.

\section{KESIMPULAN}

Berdasarkan pemaparan tersebut bahwa perbankan syariah merupakan bank yang dalam operasionalnya berdasarkan prinsip-prinsip syariah baik dalam penghimpunan dana dengan prinsip wadi'ah dan mudharabah; dalam pembiayaan menggunakan prinsip jual beli murabahah, salam dan istishna; dalam mengeluarkan produk jasa bank syariah menerapkan prinsip al-wakalah, al-hiwalah, al-qardh, al-kafalah dan al-rahn. Ketiga produk tersebut bila ditinjau secara yuridis telah menerapkan Undang-Undang Nomor 21 tentang Perbankan syariah, dan dalam perspektif filosofis telah sesuai dengan Pancasila, UUD 1945 dan Qur'anHadis, sedangkan dalam perspektif sosiologis prinsip-prinsip tersebut telah membudaya di masyarakat Indonesia dengan kerjasama di bidang pertanian "maro, mertelu" di bidang peternakan biasanya "mertelu", sehingga dikatakan bahwa secara sosiologis prinsip syariah telah populer di masyarakat Indonesia.

14 Sudikno Mertokusumo, Mengenal Hukum Suatu Pengantar, Liberti, Yogyakarta, 1999, hal. 71-75 


\section{DAFTAR PUSTAKA}

Adiwarman A. Karim, Bank Islam Analisis Fiqih dan Keuangan, PT. Raja Grafindo Persada, Jakarta, 2010.

C. S. T. Kansil dan Christine S. T. Kansil, Kitab Undang-Undang Perusahaan, Pradnya Paramita. Jakarta, 200.

Dadan Muttaqien, Sistem Perbankan Syariah di Indonesia dalam Perspektif Politik Hukum, Disertasi Universitas Diponegoro, Semarang, 2007.

Djuhaendah Hasan, Analisis Hukum Ekonomi Terhadap Hukum Perbankan di Indonesia, disampaikan dalam Penataran Dosen Hukum Perdata dan Ekonomi seluruh Indonesia yang diselenggarakan oleh Fakultas Hukum UGM 18-23 September 2000 di Yogyakarta.

Heri Sudarsono, Bank dan Lembaga Keuangan Syari'ah Deskripsi dan Ilustrasi, Penerbit Ekonisia UII, Yogya, 2004.

Hikmanto Juwana, Analisa Ekonomi Atas Hukum Perbankan, makalah disampaikan dalam " seminar tentang "Pendekatan Ekonomi Dalam Pengembangan Sistem Hukum Nasional Dalam Rangka Globalisasi" diselenggarakan oleh Fakultas Hukum UNPAD bekerjasama dengan Bappenas, Bandung, 30 April 1998

Ismail Muhammad Syah, Filsafat hukum Islam, Bumi Aksara, Jakarta, 1999.

Jonathan R. Macey and Miller, Geoffrey, P. Banking law and Regulation, Littlle, Brown and Company, Boston, Toronto, London, 1992.

Juhaya S. Praja, Epistemologi Syara' mencari Format Baru Fiqh Indonesia, Pustaka Pelajar, Yogyakarta, 2009.

Muhammad Syafi'I Antonio, Bank Syariah Dari Teori ke Praktik, Gema Insani, Jakarta, 2001.

Mustaghfirin, Rekonstruksi Sistem Hukum Perbankan di Indonesia Kajian dari Aspek Filososfis, Sosiologis dan Budaya, Unissula Press, Semarang, 2006.

Nindyo Pramono, Hukum Perbankan Suatu Kajian dari Perspektif Hukum Ekonomi, disampaikan dalam Penataran Dosen Hukum Perdata dan Ekonomi seluruh Indonesia yang diselenggarakan oleh Fakultas Hukum UGM 18-23 September 2000 di Yogyakarta.

Sudikno Mertokusumo, Mengenal Hukum Suatu Pengantar, Liberti, Yogyakarta, 1999.

Undang-Undang Nomor 21 Tahun 2008 Tentang Perbankan Syariah

Undang-Undang Nomor 21 Tahun 2008 tentang Perbankan Syariah dan Peraturan Bank Indonesia Nomor : 9/19/PBI/2007 sebagaimana diubah menjadi Peraturan Bank Indonesia Nomor : 10/16/2008 tentang Pelaksanaan prinsip syariah dalam Kegiatan Penghimpunan dana dan penyaluran dana serta pelayanan jasa bank syariah. 